US biotechnology

\section{Information instead of products}

Fort Lauderdale, Florida

THE biotechnology industry has been given warning that in the absence of products or revenue it must keep the investment community up to date with as much information as possible on product development, marketing strategies and other internal management and financial plans.

"Uncertainty is the bane of existence for the stock market", said Nelson Schneider of E.F. Hutton at a meeting here sponsored by the Industrial Biotechnology Association to bring together its member companies and representatives of the investment community. Schneider and other stock analysts at the meeting noted that with so many venture capital companies going public, Wall Street finds it difficult enough as it is to evaluate their worth and that conventional methods could easily conclude that many of the biotechnology stocks are in fact worthless.

Robert Johnston of Johnston Associates pointed out that valuations based on such traditional methods as comparisons with other stocks are of little value in biotechnology, where expectations, supply and demand of the stocks and the "greater fool theory" - the belief that a stock is a bargain because someone else is willing to pay more - operate.

Robert Fildes, president of Cetus, retorted that the new biotechnology companies were being asked by the analysts to "take down their trousers", while the pharmaceutical companies' privacy was respected. And he dismissed the analysts' arguments

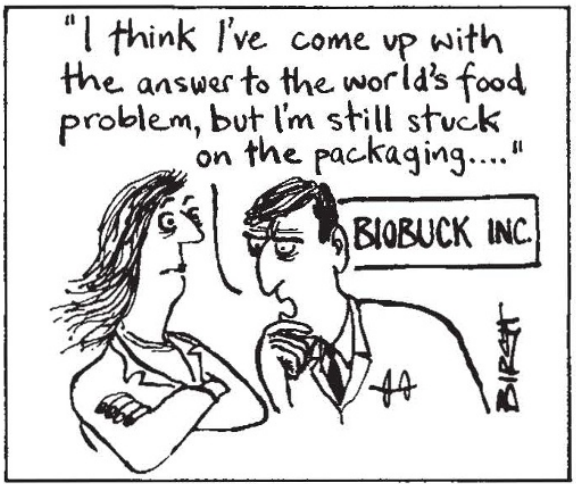

that the pharmaceutical companies can be rated by their track record and product stream: "What you're saying is that they have a bigger war-chest than we do", he said, "'but they'll go under too, eventually, if they don't produce"'

Many of the industry's representatives noted that going public is an essential step in raising the funds needed to become a business selling products rather than being merely a research and development firm. Hugh D'Andrade of Schering-Plough said that his company has a sales force of over 5,000 . "It's more than brilliant scientists who turn discoveries into products." D'Andrade said that manufacturing expertise, quality control, packaging and management are crucial elements that many of the new biotechnology companies are only beginning to assemble.

The hazards of going public, however, are sufficient to stop some, at least for the time being. Gabriel Schmergel, president of the Genetics Institute, said his company would remain private for the "foreseeable future". He was conscious of the pressures of going public, one of which is the very uncertainty the market feels for the industry. "The long-term nature of our business is not fully appreciated by the public", he said. Fluctuations in the value of stock on the market can be particularly unnerving, he said, both for management and for the staff who own stock.

A number of biotechnology companies, including Genex, Agrigenetics and Genentech, have resorted recently to commercial bank loans to support their operations, which Schneider said may indicate "a useful new movement",

Stephen Budiansky

\section{Washington}

HARVARD University is embarrassed in its efforts to sell the rights to a fundamental genetic engineering process developed by Professor Mark Ptashne, a Harvard faculty member. After approaching hundreds of companies, Harvard has succeeded in interesting fewer than a half dozen in purchasing a licence to the pair of patents covering Ptashne's invention.

Harvard was trying to duplicate Stanford University's success with the Cohen-Boyer genetic engineering patent, which currently has 68 licensees, each paying a fee of $\$ 10,000$ a year against future royalty payments of $1 / 2$ per cent of another fundamental step in genetic engineering: the method for attaching a bacterial promoter to a gene of nonbacterial origin, such as that coding for human growth hormone. Harvard, which also wanted $\$ 10,000$ a year and $1 / 2$ per cent royalty on sales, apparently misread both the importance of the Ptashne patents and the mood of the industry. Ironically, Genetics Institute, the Boston-based biotechnology company that Ptashne founded and with which he remains closely associated, did not even take out a licence; its president, Gabriel Schmergel, said that Harvard's terms were "onerous" and that "alternative routes to achieve the same end result" of the Ptashne process are

Albert Halluin, patent counsel for Cetus Corporation, attributed the poor response to the reluctance biotechnology companies to head down a path of a whole series of net sales. The Ptashne patent covers available.

Nuclear Pakistan "Islamic bomb" scare resurfaces

THE vexed question of Pakistan's nuclear capability has surfaced again, first in rumours widely reported last month in the Asian press, but since strongly denied, that China had supplied Pakistan with nuclear bombs and second through a published interview with a leading Pakistani nuclear scientist, Dr Abdul Qadeer Khan, director of the Kahuta uranium enrichment plant.

In this interview, which appeared first in the newspaper Nawa-e Waqt, and was repeated next day on Lahore radio, Dr Khan said that he felt "cornered" by questions about a possible Pakistani bomb, and did not know whether to answer yes or no. This remark immediately produced a counterblast from Soviet television which alleged that Dr Khan had boasted that it was within Pakistan's capability to create its own bomb. (The Soviet commentator incidentally identified Dr Abdul Qadeer Khan as head of the Pakistani Atomic Energy Commission - a

\title{
Harvard's Ptashne patent disappoints
}

basic process patents, each taking a $1 / 2$ per cent bite out of sales. And he says that the companies have become much more knowledgeable about patents. "After the history of the Cohen-Boyer patent"' - the validity of which has come under considerable question since the companies first signed up - "people are saying maybe we should take a hard look at these. Now people have learned that any patent may have flaws if you look hard enough."

Halluin also noted that many companies took licences to the Cohen-Boyer patent at least partly to show that they were "one of the club" of new biotechnology companies. On that basis, and with a cutprice initial licensing offer, Stanford collected more than $\$ 3$ million from licensees even before the first products were sold. Harvard also announced that stiffer licensing terms would operate after termination of the initial of fering - at the end of 1983.

Schmergel cited another reason behind his company's decision: he said Genetics Institute was "upset" by what he termed Harvard's preferential treatment in the granting of exclusive licences on some of its other biotechnology patents to companies founded by the original inventors of the patents - in particular Dr Walter Gilbert of Biogen and Dr Max Essex of Cambridge Biosystems.

Schmergel said Genetics Institute had discussed with Harvard the possibility of obtaining an exclusive licence on the Ptashne patent but had been unable to reach an agreement.

Stephen Budiansky 